\title{
ANALYSIS OF PHARMACEUTICAL WORKERS RECOMMENDATIONS FOR WOUND-HEALING DRUGS IN UKRAINE
}

\author{
Kondratskyi Arsenii ${ }^{1}$, Glushchenko Olena ${ }^{2}$, Butkevych Tetiana ${ }^{2}$ \\ ${ }^{1}$ Student of Pharmaceutical faculty, O. O. Bogomolets National Medical University, Kyiv, \\ Ukraine \\ ${ }^{2}$ Department of pharmacy and industrial technology of drugs Bogomolets National Medical \\ University, Kyiv, Ukraine
}

\begin{abstract}
The occurrence of superficial wounds remains one of the most significant problems all the time among different types of household injuries. Up to $40 \%$ persons annually have such damages of the skin like abrasions, scratches, cracks, suppurations, cuts, bedsores, and others. The problem of choosing a suitable drug arises acutely, since most pharmacists consider the issue of treatment by themselves. Patient's referral to hospital departments for doctors advise remains minimal. Pharmacy specialists carry out pharmaceutical care and perform a personal analysis due to the given initial information about the mechanism, place of occur, size of wound and stage of the process of wound healing. Considering previous experience in fulfilling customer needs, they select optimal remedy, determine the majority of choice and thus, may be identified as the sales leaders. As for January 2021, the range of topical drugs used for the treatment of wounds numbered 270 trade names according to the State registry of medicines of Ukraine. They included 62 types of active pharmaceutical ingredients. Antimicrobial (antiseptic), anti-inflammatory, decongestant, protective and emollient action properties are underlined in their pharmaceutical inserts. It is similar for most of the medicines that are available on the Ukrainian pharmaceutical market. After all, their effectiveness to satisfy a patient need is as different as the price point. The choice of the optimal in composition and rational in the dosage form causes certain difficulties among the available wide range of medicines. Registrated semi-solid wound-healing drugs are represented by three groups of ATC classification: D03 - drugs for wounds and ulcers, D06 - antibiotics and chemotherapeutic drugs for use in dermatology, D08antiseptic and disinfectant drugs (table 1). Ointments predominate among semi-solid dosage forms with range $67.3 \%$, creams $-26.5 \%$, gels $-10.2 \%$, liniments $-6.1 \%$, and jellies only $2.0 \%$ of the market. $59.2 \%$ of semi-solid wound-healing drugs are produced by domestic enterprises, and 40.8\%by foreign manufacturers. The recommendations for the use of semi-solid drugs were distributed as follows: for the first phase of wound process $-48.9 \%$, for the first and second phases $-12.2 \%$, for the second phase - $10.2 \%$, for the second and third phases - $26.4 \%$, for the third phase- $2.0 \%$.

The article summarizes the results of a questionnaire of pharmaceutical specialists on the available and free sale wound-healing medicines among registered on the Ukrainian market, that are most promoted and recommended. The purpose of our work was to single out available and free sale wound-healing medicines among registered on the Ukrainian market, that are most promoted and recommended by pharmaceutical specialists. This would help to highlight the real picture of sales, to analyze the components of leading products and, as a result of additional research, to propose a model for the complex pharmaceutical development of a new wound-healing medicine in a rational dosage form with safe and effective active ingredients of plant origin, and, consequently, competitive for pharmaceutical manufacturers. The list of registered medicines was composed in accordance with the data from the State Register of Medicines of Ukraine (registrated trade names). The total number of respondents was 176. Questionnaire survey was the main method of information's collecting: 46 respondents were interviewed individually, 130 persons of the target audience - by electronic form.
\end{abstract}

Cite as: Analysis of pharmaceutical workers recommendations for wound-healing drugs in Ukraine 
Questionnaire contained the same questions for the individual survey and online one. Questionnaire contained particular situational tasks and questions related to the practical experience of the pharmaceutical specialists: 12 questions, among which 5 questions provided an answer in detail. Whole data was analyzed systematically and statistically. 342 reviews on 36 medicines trade names were received while answering the question about the drug's recommendation for quick healing of abrasions and scratches. Various drugs promoting rapid injury healing ( $B$ Bepanten ${ }^{\circledR}$ 》 ointment, "Levomekol» ointment, «Pantestin-Darnitsa $\left.{ }^{\circledR}\right\rangle$ gel and «Riativny ${ }^{\circledR} 》$ cream) determined in the most mentioned requests. We found out that most pharmaceutical specialists chose semi-solid dosage forms containing dexpanthenol for light burn wounds healing ("Bepanten ${ }^{\circledR} »$ cream and ointment, "D-panthenol», "Pantecream», "Pantexol-Jadran», "HepiDerm-Zdorovye»). Pharmaceutical specialists recommend «Contractubex ${ }^{\circledR} »$ and «Solcoseryl» mostly to improve wound healing and minimizing the development of a cosmetic scar. Only 1/3 of respondents would recommend to a pharmacy visitor to exam skin defect by doctor or cosmetician and get reliable advice. The recommendations of pharmaceutical specialists for shallow cuts were predominantly determined by antiseptic drugs - most of them chose iodine solutions. 264 reviews were received for 32 trade names of medicines as effective treatment for bedsores. Respondents preferred zinc oxide preparations usage. According to the investigation, the opinions of the interviewed pharmaceutical specialists were focused on the semi-solid dosage forms (ointments, creams etc) for various wound care (abrasions and scratches, burns, scars, bedsores). Dosage forms of medicines for the treatment of cut wounds were an exception. Solutions and new kind of plasters - Skin glue, were the drugs of choice in this group. Phytomedicines practically did not appear among the respondents answers.

Key words: assortment, pharmacies, questionnaire of pharmaceutical specialists, semi-solid dosage forms, wound-healing medicines.

Introduction. There is no doubt that most of the damages are unintentional. Wounds should be called as skin injuries associated with a break of the skin integrity by mechanical factor. Wounds are characterized by gaping of the outer lining, bleeding and pain and may be classified into stabbed, cut, torn, bite, burn, gunshot etc wounds. Also, wounds are classified, based on how long they take to heal, as acute, and chronic ones (Ashalatha, Vaidya \& Pooja, 2020). Most often, direct contact with a foreign body infects wounds. This can lead to suppuration, especially in advanced cases or when first aid has not been provided at time. Wounds healing is complicated due to increase of antibiotic-resistant microorganisms, extensive use of chemically active ingredients (Podorozhna, Gladukh \& Stepanenko, 2020), which can lead to unwanted allergic (side) effects, and infrequent referral to the doctor for medical advice. Pharmaceutical specialists are primarily those who most often provide advice on the choice of a medicine depending on the nature of the wound surface and the stage of the process of wound healing: first phase - inflammation, second phase - regeneration and third phase - epithelialization of tissue (Datsenko, Belov \& Tamm, 1985, Datsenko, 2007, as cited in Glushchenko, 2020). This was seen in Glushchenko (2020) study of wound-healing medicines assortment on pharmaceutical market of Ukraine for January 2020, that among medicines recommended for use in first phase of wound healing process, dominate drugs with antimicrobial action, in first-second phases of wound healing process - medicines with antimicrobial, analgesic, reparative and anti-inflammatory action; in second-third phases of wound healing process -antimicrobial and reparative action medicines.

Understanding the exact mechanisms which is involved in the process of wound formation is necessary to select the optimal type of therapy.

Abrasions are isolated lesions of the epidermis, clinically not manifested by bleeding. A disturbance of blood circulation and lymph flow slow the epithelialization and leads to the recurrence of skin defects. Mostly, they are the simplest of all 
injuries due to the terms of wound healing, and ability not to leave any scar after treatment. They are the most common form of injury in children accounting for $70.7 \%$ of all injuries. Abrasions can be classified into linear or scratch, grazed and patterned types (Shrestha., Krishan \& Kanchan, 2020).

This was seen in Zhong, Ahmad, Xing., Yamada \& Hamel (2008) that «a bedsore or pressure ulcer is an area of localized damage to the skin and underlying tissue caused by pressure, shear, friction, or a combination of these factors». Areas exposed to long-term systematic pressure or which form due to the neurotrophic disturbances lead to the appearance of bedsores in weakened long-lying patients (ulcerative-necrotic, dystrophic changes). With bedsores, foci of inflammation are formed, the risk of infection increases.

Extreme temperature coagulates skin proteins, which leads to their death. Violation of microcirculation turns up, the skin surface becomes hyperemic, the interstitium swells. Skin lesion is deeper and thermal burns are significant with more critical temperature and longer time of exposure. It is always needed the "adequate fluid replacement, nutritional support, and immediate wound grafting» to reduce the risk of infection (Wardhanal \& Halim, 2020). It is needed to understand, that «different causes lead to different injury patterns», which require different medicational treatment depending on the body's response to a burn, is it local or systemic one (Hettiaratchy \& Dziewulski, 2004). And only if burn injuries are local and have a little area, patient can consider a pharmaceutical specialist's recommend of a medicational form for its healing. Eighty thousand cases of burns are registered in Ukraine every year (Glushchenko, 2020).

Any wound that is penetrating the dermis (injuries, surgeries, burns, acne) heals with scarring process. Sometimes wounds on the skin are subject to excessive scarring, which leads to hypertrophic and keloid scars obtaining. Their occurrence explains by the injury of the basement membrane and healing of the tissue by secondary tension. Most of such scars skin changes cause not only aesthetic, but also functional disorders that affect the quality of life (Avetikov, Stavytskyy, Trapova, \& Rozkolupa, 2013). For example, scars after acne occur due to different factors, such as androgen, bacteria, immunology, genetics and external factors such as medicines and cosmetics that were used during treatment (Mascaro, 2000). This was seen in Avetikov et al. (2013) that «approximately 25 million people worldwide occur each year pathological scars»».

Based on the analysis of numerous scientific medical sources, it was found that there is no single view on the etiology, pathogenesis, treatment and prevention of pathological scars.

It is necessary to take into account many pathological link and pathways to eliminate the decisive factors completely choosing the optimal composition of the medicine and dosage form.

Wound-healing medicines should have such characteristics, as safety (be not harmful not only to living tissue, but also the body in general), efficiency (be able to achieve the therapeutical purpose without affecting natural wound healing process), ease of use (Atiyeh et al., 2009, as cited in Ismail et al., 2015).

The occurrence of superficial wounds remains one of the most significant problems all the time among different types of household injuries. Up to $40 \%$ persons annually have such damages of the skin like abrasions, scratches, cracks, suppurations, cuts, bedsores, and others. The problem of choosing a suitable drug arises acutely, since most pharmacists consider the issue of treatment by themselves. Patient's referral to hospital departments for doctors advise remains minimal. Pharmacy specialists carry out pharmaceutical care and perform a personal analysis due to the given initial information about the mechanism, place of occur, size of wound and stage of the process of wound healing. Considering previous experience in fulfilling customer needs, they select optimal remedy, determine the majority of choice and thus, may be identified as the sales leaders (Sen, 2019).

As for January 2021, the range of topical drugs used for the treatment of wounds numbered 270 trade names according to the State registry of medicines of Ukraine. They included 62 types of active pharmaceutical ingredients. Antimicrobi- 
al (antiseptic), anti-inflammatory, decongestant, protective and emollient action properties are underlined in their pharmaceutical inserts. It is similar for most of the medicines that are available on the Ukrainian pharmaceutical market. After all, their effectiveness to satisfy a patient need is as different as the price point. The choice of the optimal in composition and rational in the dosage form causes certain difficulties among the available wide range of medicines.

Registrated semi-solid wound-healing drugs are represented by three groups of ATC classification: D03 - drugs for wounds and ulcers, D06 antibiotics and chemotherapeutic drugs for use in dermatology, D08 - antiseptic and disinfectant drugs. Ointments predominate among semi-solid dosage forms with range $67.3 \%$, creams $26.5 \%$, gels $-10.2 \%$, liniments $-6.1 \%$, and jellies only $2.0 \%$ of the market. $59.2 \%$ of semi-solid wound-healing drugs are produced by domestic enterprises, and $40.8 \%$ - by foreign manufacturers. The recommendations for the use of semi-solid drugs were distributed as follows: for the first phase of wound process $-48.9 \%$, for the first and second phases $-12.2 \%$, for the second phase $-10.2 \%$, for the second and third phases $-26.4 \%$, for the third phase $-2.0 \%$.

The analysis of semi-solid wound-healing drugs by the origin of active substances proved the advantage of synthetic origin ones $-89.7 \%$, only $8.1 \%$ contain plant origin substances, only $2.2 \%$ - animal origin substances. The majority of semi-solid wound-healing drugs are monocomponent $-63.2 \%$.

The purpose of our work was to single out available and free sale wound-healing medicines among registered on the Ukrainian market, that are most promoted and recommended by pharmaceutical specialists. This would help to highlight the real picture of sales, to analyze the components of leading products and, as a result of additional research, to propose a model for the complex pharmaceutical development of a new wound-healing medicine in a rational dosage form with safe and effective active ingredients of plant origin, and, consequently, competitive for pharmaceutical manufacturers.
Materials and Methods. The list of registered medicines was composed in accordance with the data from the State Register of Medicines of Ukraine (trade names of registrated active pharmaceutical ingredients were used). Besides, such service portals like tabletki.ua and compendium. com.ua were used too. The Anatomical Therapeutic Chemical (ATC) code assigned to each drug was listed appropriately to ATC classification system.

The total number of respondents was 176 . Questionnaire survey was the main method of information's collecting: 46 respondents were interviewed individually (the survey was conducted in Kyiv pharmacies during the internship of O. O. Bogomolets National Medical University pharmaceutical faculty students), 130 persons of the target audience - by electronic form. The questionnaire contained the same questions for the individual survey and online one. Questionnaire contained particular situational tasks and questions related to the practical experience of the pharmaceutical specialists. The questionnaire contained 12 questions, among which 5 questions provided an answer in detail. Whole data was analyzed systematically and statistically using MS Access, MS Excel, and Power Quarry software.

Work experience and education level varied among the interviewed specialists (table 1).

Results and discussion. Different answers were received depended on the ownership of pharmacies, work experience, age, self-education of pharmaceutical specialists.

Analyzing the answers to the questions of situational tasks, we have received and structured the following results.

Question 1. A young man, who fell on the asphalt and injured a small area of his skin, comes to your pharmacy with a request to help to choose a needful medicine. What drug would you recommend for quick healing of abrasions and scratches?

In total 342 reviews on 36 medicines trade names were received. They can be conventionally divided into 3 categories: medicines containing antibiotics, antiseptics and various drugs promoting rapid injury healing. 
Table 1. Results of questioning, concerning work experience and education level of respondents

\begin{tabular}{|c|l|l|c|}
\hline \multirow{2}{*}{ o } & Question & & Number of responses \\
\hline \multirow{3}{*}{1} & \multirow{3}{*}{ Work experience } & Under 1 year & 89 respondents $-50.6 \%$ \\
\cline { 3 - 4 } & & From 1 to 5 years & 45 respondents $-25.6 \%$ \\
\cline { 3 - 4 } & & More than 5 years & 17 respondents $-9.7 \%$ \\
\cline { 3 - 4 } & & More than 10 & 25 respondents $-14.1 \%$ \\
\hline \multirow{3}{*}{2} & \multirow{3}{*}{ Level of pharmaceutical education } & High level of education & 66 respondents $-37.5 \%$ \\
\cline { 3 - 4 } & & Secondary special education & 25 respondents $-14.1 \%$ \\
\cline { 3 - 4 } & & Students & 81 respondents $-46.0 \%$ \\
\hline
\end{tabular}

The third category was the most numerous 182 reviews. Among them 18 trade names of drugs entirely figured. «Bepanten ${ }^{\circledR}$ » ointment $5 \%$ (manufactured by GP Grenzach Produktions GmbH manufacturing company, Germany) - 31 requests, «Levomekol» ointment (product of 6 domestic Ukrainian pharmaceutical manufacturers: PJSC Viola pharmaceutical factory, PJSC Farmak, JSC Farmak, JSC Lubnyfarm, PJSC SIC Borshchahivskiy CPP, PJSC «Zhervona Zirka» CPP) - 21 requests, «Pantestin-Darnit$\mathrm{sa}^{\circledR} \gg$ gel (manufactured by PJSC Pharmaceutical company Darnitsa, Ukraine) and «Riativnyk ${ }^{\circledR} »$ cream (manufactured by JSC Kievmedpreparat, Ukraine) determined in the most mentioned requests.

We have studied 134 answers with 9 medicines trade names of antiseptics for topical application. Most often, pharmaceutical specialists recommended iodine solutions, such as «Betadin $\left.{ }^{\circledR}\right\rangle$ solution $10 \%$ (manufactured by CJSC Pharma- ceutical plant EGIS, Hungary) - 44 requests, and «Povidone-iodine» liniment $10 \%$ (manufactured by PJSC SIC Borshchahivskiy CPP, Ukraine) 22 requests.

Only 26 reviews were obtained with regard to 9 medicines with antibiotics. «Baneocin Ointment» (manufactured by Sandoz and $P \& G$ Health Austria GmbH \& Co manufacturing, 10 requests), «Synthomycin» liniment $5 \%$ (that is manufactured by two companies - JSC Lubnyfarm and PJSC «Zhervona Zirka» CPP, Ukraine 6 requests totally) turned out most recommended.

Some pharmaceutical specialists gave exceptional advice in proposed simulated situation. For example, this was washing wounds with a hypertonic solution of sodium chloride or using laundry soap as a treatment.

Question 2. A young woman touched a hot kettle at home. She developed a mild burn. The next day, she asks help to find a medicine. What would you suggest to a customer with burns?

\begin{tabular}{|c|c|c|c|}
\hline № & Group of medicines & $\begin{array}{c}\text { Number of } \\
\text { responses }\end{array}$ & Trade name of medicine \\
\hline 1 & $\begin{array}{l}\text { Semi-solid dosage forms containing } \\
\text { dexpanthenol }\end{array}$ & 140 & 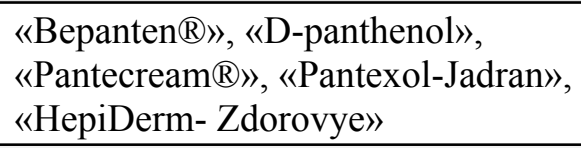 \\
\hline 2 & $\begin{array}{l}\text { Semi-solid dosage forms containing } \\
\text { combination of dexpanthenol and } \\
\text { chlorhexidine }\end{array}$ & 2 & «HepiDerm plus» \\
\hline 3 & $\begin{array}{l}\text { Semi-solid dosage forms with medical plant } \\
\text { components }\end{array}$ & 10 & $\begin{array}{l}\text { «Calendula ointment», «Symphytum } \\
\text { ointment» }\end{array}$ \\
\hline 4 & $\begin{array}{l}\text { Semi-solid dosage forms containing } \\
\text { components of animal origin }\end{array}$ & 14 & «Solcoseryl» \\
\hline 5 & $\begin{array}{l}\text { Semi-solid dosage forms containing } \\
\text { methyluracil (also in combination) }\end{array}$ & 85 & $\begin{array}{l}\text { «Levomecol», «Levosin», } \\
\text { «Methyluracil \& myramistin» }\end{array}$ \\
\hline
\end{tabular}

Table 2. Results of questioning, concerning choice of medicine for burn care 
We found out that most pharmaceutical specialists chose semi-solid dosage forms containing dexpanthenol (55.8\% of all respondents) for light burn wounds (table 2). «Bepanten ${ }^{\circledR} 》$ cream and ointment (manufactured by Gp Grenzach Produktions $\mathrm{GmbH}$ manufacturing company, Germany) were recommended in $36.7 \%$ of all requests (and this is $65.7 \%$ among all trade names of the proposed group of drugs).

Question 3. A woman after undergoing $a b$ dominal surgery 2-3 weeks ago worries about the formation of an unaesthetic defect. What would you advice to improve wound healing and minimizing the development of a cosmetic scar?

Specific trade names of medicines ( $«$ Contractube ${ }^{\circledR} \gg$ gel manufactured by Merz Pharma GmbH\& Co.KGaA, Germany; «Solcoseryl» gel and ointment manufactured by Legacy Pharmaceuticals Sweetseland GmbH, Switzerland), instruction to indicate other answer option and instruction to consult a doctor were the answers to this situation task question.

Only $34.1 \%$ of respondents (60 interviewed pharmaceutical specialists) would recommend to a pharmacy visitor to exam skin defect by doctor or cosmetician and get reliable advice.

60 respondents $(34.1 \%)$ chose «Contractubex ${ }^{\circledR} \gg, 29(16.5 \%)$ requested «Solcoseryl» and $27(15.3 \%)$ persons indicated 17 other pharmaceuticals, dietary supplements, cosmetic products. Other results included «Contrarubets» gel (manufacturing company Cortes LLC, Ukraine) 6 requests, «Strataderm» gel (Stratpharma, Switzerland manufacturer) -5 requests and «Dermofibrase» cream (Georg BioSystems LLC, Ukraine manufacturer) -2 requests.

Question 4. The young man cut superficially the back of his forearm during washing the dishes. The damage was minor, the bleeding stopped. Which of the drugs, in your opinion, is preferable and will accelerate the healing of the cut wound?

The recommendations of pharmaceutical specialists for shallow cuts were predominantly determined by antiseptic medicines ( $68.2 \%$ of the received responses). Most of the specialists chose iodine solutions -42 requests $(23.9 \%)$. Hydrogen peroxide solutions $3 \%$ also did not lose demand - 17 requests $(9.7 \%)$. Dilute ethanol solu- tion of brilliant green, calendula tincture, etc. occurred in the minority of questionnaires (1-2 responses of respondents).

The most part of young pharmaceutical specialists (with work experience up to 5 years) hold the opinion, that skin glue is one of the perspective dosage forms for healing of shallow cuts (21.9\% of the received responses).

Question 5. What do you think is the most effective treatment for bedsores?

Bedsores were shown as typical variant of purulent (septic) wound. Generally, 264 reviews were received for 32 trade names of medicines. The obtained survey data showed the advantage of antiseptics as drugs of choice over antibiotic containing ones $(56.4 \%)$. In particular, 69 requests $(26.1 \%)$ of respondents preferred zinc oxide preparations usage. Among this group of drugs «Sudocrem» (manufactured by Tosara Pharma Ltd, Ireland) become most common in all answers - $15.5 \%$.

Respondents also suggested other medicines for wound healing. For example, medicines with silver and sulfathiazole such as Argosulfan ${ }^{\circledR}(12.2$ $\%)$, dexpanthenol based medicines - «Bepanten», «Pantecream ${ }^{\circledR} »$, «Pantexol-Jadran», «HepiDerm-Zdorovye», and combinations of dexpanthenol with chlorhexidine («HepiDerm plus») or with miramistin $\left(«\right.$ Pantestin- Darnitsa $\left.\left.{ }^{\circledR}\right\rangle\right)-6.1 \%$ and $5.3 \%$, respectively.

Additionally, some pharmaceutical specialists noted among other answers usage of such means and methods as herbal ointment «Woundaheal», aerosol «Kadefort», «Dioxizol-Darnitsa ${ }^{\circledR} 》$ » solution, chlorophyllipt oil solution, camphor alcohol solution, application of hydrocolloid bandage and tampons moistened with calendula tincture.

A separate point of our research was to study the demand for various types of dosage forms in the treatment of cut wounds. This question was interesting for us, for future choice of optimal and rational dosage form as an object of new wound-healing medicine's pharmaceutical development. We have received 222 answers. Pharmaceutical specialists recommended skin glue (liquid plaster) in $25.7 \%$, bactericidal adhesive plaster $-19.8 \%$ and antiseptic solutions for cure of surficial injuries $(19.4 \%)$. The respondents answers with the indication of semi-solid dosage 
forms were $24.9 \%$ in total (cream $-9.5 \%$, ointment $-8.6 \%$, liniment $-6.3 \%$, gel $-0.5 \%$ ).

Answering the question for what did the pharmaceutical specialists guided for advising wound healing agents, the majority of respondents indicated frequent prescriptions by doctors $(40.3 \%)$, recommendations of colleagues in their pharmacy $(31.8 \%)$ and their own experience $(23.9 \%)$.

The last question in the questionnaire was about compliance with the recommendations or providing an alternative choosing of a wound-healing medicine by a pharmacy visitor. We received 97 responses (55.1\% of the total number of reviews) regarding the fact that the patient always follows the recommendations of a specialist working in a pharmacy while choosing a wound-healing drug. It was determined that the most amount of these requests $(55.7 \%)$ were given by pharmaceutical specialists with work experience over 10 years. 52 respondents $(29.5 \%)$ noted that a pharmacy visitor often follow a specialist's advice. And $13.1 \%$ of all interviewed pharmaceutical specialists requests (23 respondent's answers) showed that despite recommendations and advice the pharmacy visitor choose another medicine.

All pharmaceutical specialists noted that the provision of pharmaceutical care, and given recommendations for choosing optimal in safety, effectiveness and price wound-healing medicine, can be carried out only in the case of a small level of the patient's body tissue injuries.

\section{Conclusions.}

1. As for January 2021, the range of topical drugs used for the treatment of wounds numbered 270 trade names according to the State registry of medicines of Ukraine. They included 62 types of active pharmaceutical ingredients. Registrated semi-solid wound-healing drugs are represented by three groups of ATC classification: D03 - drugs for wounds and ulcers, D06 - antibiotics and chemotherapeutic drugs for use in dermatology, D08 - antiseptic and disinfectant drugs. Ointments predominate among semi-solid dosage forms with range of $67.3 \%$.

2. Questionnaire survey was the main method of information collecting about most promoted and recommended by pharmaceutical special- ists semi-solid wound-healing drugs. The total number of respondents was 176.

3. Different answers were received depended on the ownership of pharmacies, work experience, age, self-education of pharmaceutical specialists. For quick healing of abrasions and scratches antiseptics and various drugs promoting rapid injury healing are recommended (182 reviews). «Bepanten $® »$ ointment $5 \%-31$ requests and «Levomekol» ointment - 21 requests determined in the most mentioned requests.

4. For a customer with burns pharmaceutical specialists suggest semi-solid dosage forms containing dexpanthenol $(55.8 \%$ of all respondents).

5. To improve wound healing and to minimize the development of a cosmetic scar such specific trade names of medicines as «Contractubex ${ }^{\circledR} »$ gel, «Solcoseryl» gel and ointment are adviced.

6. Antiseptic medicines $(68.2 \%$ of the received responses) are preferable and will accelerate the healing of the cut wound in the opinion of pharmaceutical specialists.

7. As the most effective treatment for bedsores $26.1 \%$ of respondents preferred zinc oxide preparations usage.

8. According to the investigation, the opinions of the interviewed pharmaceutical specialists were focused on the semi-solid dosage forms (ointments, creams etc) for various wound care (abrasions and scratches, burns, scars, bedsores). Their share was $82.6 \%$ of the obtained requests. Dosage forms of medicines for the treatment of cut wounds were an exception. Solutions and new kind of plasters Skin glue, were the drugs of choice in this group. Phytomedicines practically did not appear among the respondents answers. We consider that develop of wound-healing effective preparations with active herbal components is actual and promising direction of research.

Funding. This study has no external funding.

Conflict of interest. None of the authors received research grants, speaker's fees from any companies and is not a member of commissions.

Consent to publication. All authors have read and approved the final version of the manuscript. All authors have agreed to publish this manuscript. 


\section{REFERENCES}

Ashalatha, Karthik G. Vaidya, \& Pooja B. (2020). Advances in wound healing and wound care technologies - a review. International Journal of Pharmaceutical Sciences Review and Research, 62 (1), 183-191.

Glushchenko, О. М. (2020). Вивчення асортименту м'яких лікарських засобів, що сприяють загоєнню ран, на фармацевтичному ринку україни. Фармацевтичний часопис, (1), 75-81. https://doi.org/10.11603/23120967.2020.1.10982

Hettiaratchy S., \& Dziewulski P. (2004). Pathophysiology and types of burns. BMJ, 328:1427. doi:10.1136/ bmj.328.7453.1427

Ismail, Z. B., Alshehabat, M. A., Hananeh, W., Daradka, M., Ali, J. F. H., \& El-Najjar, E. K. (2015). Recent advances in topical wound healing products with special reference to honey: a review. Research Opinions in Animal and Veterinary Sciences, 5 (2), 76-83.

Mascaro J. M. (2000). Pathogenesis of acne. Journal of Dermatological Treatment,11:2, 1-4. DOI: $10.1080 / 09546630050517739-1$

Podorozhna, M. G., Gladukh, I. V., \& Stepanenko, S. V. (2020). Аналіз вітчизняного ринку лікарських засобів для використання на другій фазі ранового процесу. Фармацевтичний часопис, (3), 38-45. https://doi.org/10.11603/23120967.2020.3.11446

Sen, C. K. (2019). Human wounds and its burden: an updated compendium of estimates. Advances in Wound Care, 8 (2), 39-48. https://doi.org/10.1089/wound.2021.0026

Shrestha, R., Krishan, K., \& Kanchan T. (2020). Abrasion. StatPearls [Internet]. Treasure Island (FL): StatPearls Publishing. Available from: https://www.ncbi.nlm.nih.gov/books/NBK554465/

Wardhana, A., \& Halim, J. (2020). Antioxidants Reduce Tissue Necrosis in The Zone of Stasis: Review of Burn Wound Conversion. Jurnal Plastik Rekonstruksi, 7 (1), 18-28. https://doi.org/10.14228/jpr.v7i1.292

Zhong W., Ahmad A., Xing M. M. Q., Yamada P. \& Hamel C. (2008). Impact of Textiles on Formation and Prevention of Skin Lesions and Bedsores. Cutaneous and Ocular Toxicology, 27:1, 21-28. DOI: 10.1080/15569520701856765

Аветіков, Д. С., Ставицький, С. О., Трапова, Х. О., \& Розколупа, О. О. (2013). Ретроспективний аналіз різних методик консервативного лікування рубцевозміненої шкіри на доопераційному етапі. Український стоматологічний альманах, (5), 47-9. 


\section{АНАЛІЗ РЕКОМЕНДАЦІЙ ФАРМАЦЕВТИЧНИХ ПРАЦІВНИКІВ ЩОДО РАНОЗАГОЮВАЛЬНИХ ЛІКАРСЬКИХ ЗАСОБІВ В УКРАЇНІ}

\section{Кондрацький Арсеній', Глущенко Олена $^{2}$, Буткевич Тетяна ${ }^{2}$}

${ }^{1}$ студент фармацевтичного факультету, Національний медичний університет імені О. О. Богомольця, Київ, Україна

${ }^{2}$ Кафедра аптечної та промислової технології ліків Національний медичний університет імені О. О. Богомольця, Київ, Україна

Анотація. У структурі побутового травматизму виникнення поверхневих ран залишається однією із найактуальніших проблем по всяк час. Щороку близько 40 \% населення отримують ушкодження шкірного покриву: садени, подряпини, тріщини, нагноєння, порізи, пролежні тощо. Проблема вибору підходящого лікарського засобу постає гостро, оскільки цим у більшості займаються провізори та фармацевти, а звернення до лікарів як фахівців $є$ мінімальним. Працівники аптеки здійснюють фармацевтичну опіку, проводять індивідуальний аналіз початкової інформації щодо механізму утворення раневої поверхні, аналізують попередній досвід задоволення потреб споживачів та формують так звані домінуючі лікарські засоби, що як наслідок будуть лідерами продажу. Станом на січень 2021 року асортимент зовнішніх м'яких лікарських засобів, що застосовують для лікування раневої поверхні налічує 270 торгових назв відповідно даним Державного реєстру лікарських засобів України. До їхнього складу входять 62 найменувань активних фармацевтичних інгредієнтів. У більшості наявних на ринку України лікарських засобів у інструкції для медичного застосування зазначено однаковий вид терапевтичної активності - репаративна, протимікробна (антисептична), протизапальна, в'яжуча, протинабрякова, захисна та пом'якшувальна дія. Зрештою їх ефективність за рівнем задоволення потреб пацієнтів різниться так само як і цінова категорія. 3-посеред наявного широкого асортименту лікарських засобів вибір оптимального за складом та раціонального за видом лікарської форми викликає певні труднощі. Аналізуючи фармацевтичний ринок України м'яких лікарських засобів для загоювання ран відповідно АТС-класифікації визначено, що вони представлені трьома групами: D03 - засоби для лікування ран і виразкових уражень, D06 - антибіотики та хіміотерапевтичні препарати для використання в дерматології, D08 - антисептичні та дезінфікуючі засоби. Дослідження ринку за лікарською формою довели перевагу мазей - 67,3\%. Креми займають $26,5 \%$, гелі - 10,2\%, лініменти - 6,1\%, а желе лише $2,0 \%$ ринку. Проведений аналіз показав, що 59,2 \% препаратів випускаються вітчизняними підприємствами, а 40,8 \% - закордонними виробниками. Щодо рекомендацій до застосування їх можна розподілити так: для I-ї фази раневого процесу - 48,9 \%, для I-ї та II-ї фаз$12,2 \%$, для II-ї фази - 10,2 \%, для II-ї та III-ї фаз $-26,4 \%$, для III-ї фази $-2,0 \%$.

Стаття підсумовує результати проведеного анкетування фармацевтичних фахівців щодо наявних на ринку безрецептурних ранозагоювальних лікарських засобів, які є найбільш рекламованими та рекомендованими працівниками аптечних закладів. Метою нашої роботи було виділити серед зареєстрованих на українському ринку доступні безрецептурні лікарські засоби ранозагоювальної дії, які найбільше просуваються та рекомендуються фармацевтичними працівниками. Це допомогло б висвітлити реальну картину відпуску тих чи інших найменувань лікарських засобів, провести аналіз складових лідируючих препаратів, та, як результат додаткових досліджень, у подальшому запропонувати модель комплексної фармацевтичної розробки нового ранозагоювального лікарського засобу у раціональній лікарській формі з безпечними та ефективними активними інгредієнтами. Перелік зареєстрованих лікарських засобів укладався відповідно даним Державного реєстру лікарських засобів України (зареєстровані торгові назви препаратів). Основним методом збору інформації стало анкетування, проведене індивідуально вруч- 
ну серед 46 респондентів та у електронному вигляді - 130 осіб таргетної аудиторії. Анкета містила конкретні ситуативні задачі та питання, що стосувалися практичного досвіду провізора та фармацевта. Отримані дані підлягали системному та статистичному аналізу. Анкета містила 12 запитань, серед яких 5 потребували розгорнутої відповіді. Загалом було отримано 342 відгуки на 36 торгових назв лікарських засобів при відповіді на запитання щодо рекомендації препарату для швидкого загоєння саден та подряпин. Різні препарати, що сприяють швидкому загоєнню раневої поверхні (мазь «Бепантен®», мазь «Левомеколь», гель «Пантестин-Дарниця®» та крем «Рятівник»), виявлено у найбільшій кількості відгуків. Визначено, що більшість фармацевтичних фахівців обирали м'які лікарські форми, до складу яких входить декспантенол, для загоєння легких опікових ран (крем і мазь «Бепантен®», «Д-пантенол», «Пантекрем», «Пантексол-Ядран», «ХепіДерм-Здоров'я»). Фармацевтичні фахівці рекомендують «Контрактубекс ®» гель та «Солкосерил» гель здебільшого для пришвидшення загоєння раневої поверхні та мінімізації подальшого розвитку косметичного рубця. Лише 1/3 респондентів рекомендували б відвідувачу аптеки звернутися до лікаря чи косметолога для огляду дефекту шкіри та отримати кваліфікованої консультативної допомоги. Рекомендації фармацевтичних фахівців щодо неглибоких порізів переважно визначались антисептичними препаратами. Більшість опитаних обирали розчини йоду. Отримано 264 відгуки щодо 32 торгових назв лікарських засобів для ефективного лікування пролежнів. Респонденти віддали перевагу використанню препаратів оксиду цинку. За результатами дослідження думки опитаних фармацевтичних фахівців встановлено спрямованість надання переваги м'яким лікарським формам (мазі, креми тощо) для терапії різноманітних раневих поверхонь (садна та подряпини, опіки, рубці, пролежні). Лікарські форми засобів для лікування різаних ран були винятком. Розчини та новий вид пластирів - шкірний клей, були препаратами вибору у цій групі. Варто відзначити, що фітопрепарати практично не фігурували серед відповідей респондентів.

Ключові слова: асортимент, аптека, анкетування фармацевтичних фахівців, м'які лікарські форми, ранозагоювальні лікарські засоби. 